DOI: 10.17707/AgricultForest.61.4.01

Laura BOURIAUD, Mihai Leonard DUDUMAN,

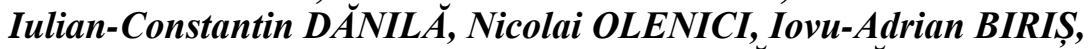
Ioan CIORNEI, Ionuț BARNOAIEA, Anca MÄCIUCÄ, Alexei SAVIN, Lucian GROSU, Mihaela MUTU, Liviu NICHIFOREL, Olivier BOURIAUD,

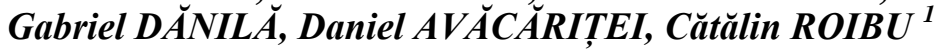

\title{
HOW TO EVALUATE THE SUSTAINABILITY OF SHORT-TERM CULTURES FOR BIOMASS PRODUCTION? AN APPLICATION FROM NE ROMANIA
}

\begin{abstract}
SUMMARY
Short rotation cultures of trees on agricultural land are implemented in various countries as to increase the European wood supply from outside the existing forest sector. However, the change of traditional agricultural land use towards intensive culture techniques may involve some environmental and social risks. The paper describes an original methodology implemented since 2011 to evaluate the sustainability of short-term biomass production. Our definition of sustainability argues that short-term rotation plantations on marginal or agricultural lands should produce benefits to local communities and industry while minimizing the environmental risks. Taking into account recommendations from sustainability literature, the methodology implemented combines various investigations on soil, biomass, biodiversity and social indicators. Results of the monitoring conducted three years in the experimental area situated in NorthEastern Romania show that one of the most accurate indicators of soil nutrient consumption was phosphorus, and that the biodiversity of poplar cultures is similar or better to that documented in agricultural land. A low level of social acceptability of poplar cultures is present, that may pose problems and creates conflicts in the long term. We argue that the methodology implemented is appropriate for a sound and objective assessment short-rotation poplar plantations impact on the overall social benefits, and to provide clear messages to investors, communities, stakeholders and policy makers.

Keywords: short term rotation cultures, sustainability, environmental indices, poplar, social acceptance.

\section{INTRODUCTION}

A major objective in energy policy all over Europe, and at the EU level, is to increase the share of renewable energies: targets have been agreed, and

\footnotetext{
1 Laura Bouriaud, Mihai Leonard Duduman, Iulian-Constantin Dănilă (corresponding author: iuliandanila@ymail.com), Ioan Ciornei, Ionuț Barnoaiea, Anca Măciucă, Alexei Savin, Lucian Grosu, Mihaela Mutu, Liviu Nichiforel, Gabriel Dănilă, Daniel Avăcăriței, Cătălin Roibu; University Stefan cel Mare of Suceava, Faculty of Forestry, str. Universității nr. 13, 720229, Suceava, ROMANIA. Nicolai Olenici, Iovu-Adrian Biriș, Olivier Bouriaud; Institutul Național de Cercetare-Dezvoltare în Silvicultură "Marin Drăcea", Bulevardul Eroilor nr. 128, Voluntari, Ilfov, ROMANIA

Note: The authors declare that they have no conflicts of interest. Authorship Form signed online.
} 
incentive systems set in place in nearly all European countries. Woody biomass accounts at present for about half of the total renewable energy supply. The EU aims to have $20 \%$ of energy from renewable sources by 2020, although individual national targets vary widely. If wood is to play its part in reaching the targets for renewable energy, there would have to be a strong mobilisation of all types of wood. Supply would have to increase by nearly $50 \%$ in twenty years (FAO-UNECE, 2011). The 2011 Forest Products Annual Market Review confirms that wood energy was the only forest related industry sector with steady economic growth even during in the economically difficult period $2008-2009$ (UNECE, 2011).

Short rotation cultures of trees on agricultural land are implemented in various countries as to increase the European wood supply from outside the existing forest sector. Short-rotation cultures of trees refers to silvicultural systems designed to produce woody biomass using short harvest cycles (1-15 years), intensive silvicultural techniques, high-yielding varieties, and often coppice regeneration (Dickmann, 2006; Riffell et al., 2011). Nevertheless, their extension involves barring the opportunity costs with other land uses and, depending on site selection processes, landscape and biodiversity (UNECE, 2011).

Romania has a large potential for afforestation of marginal lands (MEF, 2010). Badlands area, improper for agriculture, is estimated at 2,17 million ha, mostly situated in hilly and mountain region, while areas abandoned from agriculture or husbandry is likely to steadily increase in the next years. In the same time, the recent investments in huge capacities for wood processing industry in Romania has created a shortage for raw material and increased competition for forest resource (Austroprojekt, 2008). The rush for wood in timber processing and the relatively good availability of land in Romania, together with policy measures taken in the latest years for afforestation (MEF, 2010; Monitorul Oficial, 2010; MAFRD, 2010), leading to an yearly average of 2814 ha afforestation, created opportunities for development of industrial woodbiomass production systems outside the forest area, as complementary to the of forest-based products.

As a result of above-mentioned market- and policy-driven processes, short-term rotation plantations to provide industrial raw material (for energy, wood manufacturing, pulp, pharmaceutical, bio-refineries) are likely to develop on large areas during the next decades as an entrepreneurial alternative for cheaper and secured raw material procurement.

However, change of land use towards intensive culture techniques may involve some ecological risks, e.g. higher rate use of soil nutrients, massive utilisation of fertilisers and chemical pest and weeds control substances, with effects on soil micro-fauna, nutrients balance, water and soil pollution, monotony of landscape, etc. Equally, change of land use towards biomass production for industrial purposes involves as well social risks, e.g. higher competition on remaining land, increasing conflict when rural demand is neglected (afforestation of traditional grazing areas and exclusion of herds), and little benefits return to 
the local communities. In rural areas with critical shortage of fuelwood, plantation in energy-purposes may be subject of theft or destruction, while for rural communities pellets do not represent yet a competitive substituent of solid fuelwood extracted from forests. Concerns about sustainability of short-term biomass cultures rise issues related with biological diversity, economic return, rural development, traditional values or landscape transformation. The paper argues and discusses a method implemented in Northern Eastern Romania for assessing the sustainability of short term poplar culture for biomass production.

The objectives of the paper are: 1) to describe an original methodology implemented since 2011 to evaluate the sustainability of short-term biomass production, and 2) to discuss and analyse the preliminary results in the light of recent literature about sustainability of short-term biomass production. The research questions addressed are: 1) Which are the relevant aspects that deserves to be considered when assessing the sustainability of the short-term cultures? 2) What indicators are recommended and applied up to now in the literature to assess the sustainability of the biomass production? 3) Which are the contextspecific issues to be addressed when assessing the sustainability of short term cultures?

\section{Main aspects of sustainability of short rotation cultures for biomass production}

The establishment of large areas of short rotation coppice, or any other highly intensive silviculture, could make a major contribution to wood supply (Mantau et al., 2010). However, research argues that the trade-offs with biodiversity, rural landscape and biogeochemistry of soil should be assessed accurately (Fletcher et al., 2011, Riffell et al., 2011, Weih et al., 2010, Rowe et al., 2009, Carnus et al., 2006, Scholz and Ellerbrock, 2002). Therefore, analysing the sustainability of short-rotation forest plantations should consider the development of robust environmental criteria for evaluating biofuel crops, and integrated cost-benefit analysis of potential land-use change (Wang, 2014; Fletcher et al., 2011); the biodiversity status of the site and surrounding landscape, as well as the likely alternatives of the land-use for the site (Carnus et al., 2006); the organisation exante of an open and transparent public debate which would establish society's priorities for the use of a non-extendable resource, that is the rural land (Mantau et al., 2010). Hundreds of scientific papers, particularly in Biomass and Bioenergy journal, have been published to assess the productivity, the biogeochemical cycles and the environmental risks of energy crops (Scholz and Ellerbrock, 2002). Among these articles several have specifically address poplar plantations from the point of view of species productivity differences in shortrotation cultures of birch, maple, poplar and willow (Vande Walle et. al, 2007), poplar cloner differences in relation to biomass production (Pellis et all, 2004) or the dynamics of biomass production in relation to different rotations in poplar cultures (Al Afas et al, 2008, Ceulemans and Deraedt, 1999). 
However, research on woody energy crops in European context is rather scarce, and the sustainability of short-rotation cultures in its holistic meaning: ecological, economic and social elements (Wang, 2014), is rather not covered as such. One exception is the research project (2009-2013) run by a German consortium (http://probiopa.imk-ifu.kit.edu/), addressing the question of sustainability of poplar short-term rotation cultures, and integrating the economic and ecologic aspects. One have to remark still that one pillar of sustainability, e.g. the social one, is still not cover in this comprehensive project.

In Romania, research on the production and use of wood biomass for energetically purposes started in 1980 (Muşat, 1983), achieving in time significant results on the productive capacity of different poplar clones, evidence of eco-pedological indicators of the sites suitable for energetic cultures, soil preparation techniques, installation, maintenance and harvesting of crops, the influence of density, irrigation and fertilization on growth capacity of tested species and clones (Benea, 1989). A range of studies (i) identified the possibilities of using degraded land, unsuitable for agriculture, for short rotation coppiced cultures and use of biomass as alternative energy sources (Turcu, 2006), (ii) and analysed the possibilities to develop technologies to replace gaseous fuels through a combination of forest biomass and coal (Lăzăroiu, 2008) or use biomass to produce bio ethanol (Fara et al., 2009), and (iii) focused on the short cycle poplar and willow clones for bioenergy production (Fara et al., 2009; Filat and Chira, 2004). The sustainability issue, even in its narrow economic or biodiversity aspects, where not yet a subject of systematic research in Romania.

Usually energy plantations are uniform monocultures, with no structural diversity and no ground vegetation which is controlled through chemical or mechanical means. Therefore, biodiversity is a major feature of the sustainability of short rotation cultures. The man-made cultures have a simplified composition and structure which generally cause a massive species loss, and a dramatic biodiversity decline. Some specialists have described plantation as "biological deserts" (Lindberg et al, 1998). This allegation is true if the plantations are compared with natural forests but there are many biodiversity differences between various agro-forestry systems and between them and agricultural crops or degraded lands. The soil productivity was also assessed in respect to the introduction of short rotation cultures of various species, yet although soil chemical and biological properties are changed by management, the duration of those changes and their influence on productivity are not clear (Grigal, 2000).

The social and economic sustainability of short-term plantations represent a second topic that is not well studied. From a social aspect, the sustainability is related with how biomass production is perceived by society (Hall, 2002). Thevathasan et al. (2014) argue the need to include economic and social dimensions along with environmental considerations when defining sustainability. The relationship between these three aspects (economic, ecologic, social) determine the two main paradigms of the sustainability (Pearce et al., 1989; Smith and McDonald, 1998). When the three aspects are considered as 
having the same importance, the substitution of man-made and natural capital is allowed in a certain extent, and future generation should inherit assets at least equal to the current value, that is the value of both built and natural capital. For example, on the economic side, one may analyse the efficiency of converting natural forests into poplar plantations. Dragoi (2008) uses a cost-benefit analysis integrating both the use values of forest and the non-use values. The study concludes, based on economic indicators, that replacing natural forest with poplar plantations is not efficient given the fact that the loss in biodiversity is not compensated with the potential revenues. Nevertheless, the study recommends more research in the area of the contingent valuation of biodiversity in different conditions not only with natural forest ecosystems are to be replaced by poplar plantations. When the three aspects are considered to be subordinated each other, the economic sustainability can not be achieved without social sustainability, and the maintenance of ecological processes (Thevathasan et al., 2014). Understanding the sustainability in this case focuses in a central ethical postulate that is justice (Helmholtz concept, detailed by Hartmuth et al., 2008; philosophical bases laid down by Rawls, 1999). Translated in the local context of large firms implementing poplar cultures on arable land they rented or bought to the traditional communities, the social and economic sustainability would requires a kind of social contract based on corporate social responsibility of planting firms and social acceptance of plantations by the rural communities. In Romania, there are no studies carried out in respect to the social responsibility strategies that companies can integrate in order to promote the installation of plantations on marginal or agricultural land. Also, there is a need to strategically research the potential conflicts that could arise at the community level by the implementation of large-scale plantations. Such studies are done in the field on non-conventional energies, e.g. use of photovoltaic panels in rural areas (LoyolaBernard, 2012), but there are no studies for the biomass plantations on agricultural or marginal land in the European context.

\section{An integrative methodological approach to analyse the sustainability of short rotation poplar cultures}

At the international level, there are a set of rules to specify Sustainability criteria for bio-energy. The standards ISO/TC248 specifies principles, criteria and indicators for the bioenergy supply chain to facilitate assessment of environmental, social and economic aspects of sustainability. We have considered that these standards are too general for our application that have to be at local level, concerned with only poplar for biomass production to be used in industrial and energetic purposes, and limited to only two steps of the chain, namely production and primary processing.

A more appropriate method because more related with the poplar plantation specificities is that proposed by Thevathasan et al. (2014). In this paper, the authors make first a synthesis of what the sustainability means (Table 1 ), and then, they argued for a set of indicators applying purposely to monitor the 
sustainability of the short-rotation woody crop production.

Table 1. Sustainability indicators selected for an expert survey (rankings in brackets), adapted from Buchholz et al. (2009) and quoted in Thevathasan et al. (2014).

\begin{tabular}{|l|l|l|}
\hline Social & Economic & Environmental \\
\hline Compliance with laws [8] & $\begin{array}{l}\text { Employment } \\
\text { generation [22] }\end{array}$ & Adaptation capacity [13] \\
\hline Food security [11] & $\begin{array}{l}\text { Microeconomic } \\
\text { sustainability [7] }\end{array}$ & Energy balance [2] \\
\hline $\begin{array}{l}\text { Land available for activities } \\
\text { other than food production } \\
\text { [32] }\end{array}$ & $\begin{array}{l}\text { Macroeconomic } \\
\text { sustainability [27] }\end{array}$ & $\begin{array}{l}\text { Natural resource efficiency } \\
\text { [6] }\end{array}$ \\
\hline $\begin{array}{l}\text { Participation [participatory } \\
\text { democracy] [4] }\end{array}$ & Economic stability [17] & Species protection [18] \\
\hline Cultural acceptability [28] & & Ecosystem protection [9] \\
\hline Social cohesion [31] & & Ecosystem connectivity [25] \\
\hline Human rights [27] & & Crop diversity [14] \\
\hline Working conditions [15] & & Exotic species [30] \\
\hline Respect for minorities [29] & & $\begin{array}{l}\text { Use of genetically modified } \\
\text { organisms [24] }\end{array}$ \\
\hline Standard of living [33] & & Use of chemicals [19] \\
\hline Property rights [22] & & Soil protection [3] \\
\hline Planning [16] & & Land use change [23] \\
\hline $\begin{array}{l}\text { Monitoring of criteria } \\
\text { performance [10] }\end{array}$ & & Water management [5] \\
\hline Visual impacts [35] & & Waste management [12] \\
\hline Noise impacts [34] & & Greenhouse gas balance [1] \\
\hline & & $\begin{array}{l}\text { Hazardous emissions (other } \\
\text { than GHG's) [20] }\end{array}$ \\
\hline
\end{tabular}

Thevathasan et al. (2014) paper recommends a set of indices for monitoring the short rotation woody crops classified in: environmental air indices (Greenhouse gases emissions, air quality); environmental soil indices (soil nitrogen, phosphorus, total organic matter, erosion, bulk density); environmental water indices (water quality, water availability index, nitrate, biological oxygen demand and chemical oxygen demand); environmental biodiversity index, soil biota index; economic indices (microeconomic indicator; on-farm employment); social indices. For this latter, the authors point out the relative lack of social indicators and the requirement to develop new indices.

Taking into account these recommendations, we have implemented a four years research experiment (see Box 1 for project description) with the goal to figure out and characterise wherein short-term rotation plantations on marginal or agricultural lands can produce benefits to local communities and industry while minimizing the environmental risks. In doing such, we have adopted the second paradigm on sustainability, e.g. 1) all the pillars (economic, environmental and social) are important, 2) the values of natural and 
human-made capital, or between the generations can not substitute each other, and therefore 3) a compromise should be find between the economic needs of wood industry, economic and social needs of rural communities, and environmental protection (the three pillars are subordinated each other). A second important methodological choice is related with the reference state. In the absence of distinct values that can be considered as threshold of sustainability (Thevathasan et al., 2014), we have chosen a scenario-based assessment, e.g. we have recorded and compared the level of several indices for the short-term poplar plantation and for alternative (or past) land uses (regular agricultural crops specific for the region, pastures, abandoned land, recently cultivated lands with long-term forest plantations). Thus, assessing the sustainability of short-term poplar plantations was structured along several axis of experimental design:

1. to assess the evolution of soil condition (nutrients, texture) during the plantation cycle, and compare it with (past) and alternative land uses;

2. to evaluate and monitor the biodiversity of key-species in short-term plantations and alternative land uses;

3. to assess the biomass production in different cultivation schemes;

4. to assess the social sustainability of short-term poplar plantation for the biomass production with respect to 1 ) the scarcity of the resource land and 2) the social acceptability of this change in the traditional land-use.

5. to integrate the sustainability indicators in Guidelines of good practices to be discussed with the main stakeholders

The experimental design was implemented in the Northern Eastern Romania, in a hilly region (47.50' N, 25.57' E) where more than 300 ha of poplar plantations were installed by an investor in the spring of 2011 on land that had agricultural uses in the past (Figure 1). A special designated area of 3.5 ha was created for biomass assessment according to the research protocol established in 2012.

Title: Sustainability of short-term rotation cultures of trees on marginal lands (STRoMA)

http://www.silvic.usv.ro/stroma/prezentare_en.php

Project number: PNII-PT-PCCA-2011-3.2-1574 / Contract number 119/2012

Funding Authority : Unitatea Executiva pentru Finantare a Invatamantului

Superior, a Cercetării, Dezvoltării si Inovării (UEFISCDI)

Project duration: 20.07.2012 - 19.07.2016

Total budget: 212000 euro

Public funding: 180200 euro

Cofinancing (private) funding: 31800 euro

Box 1. Project description 


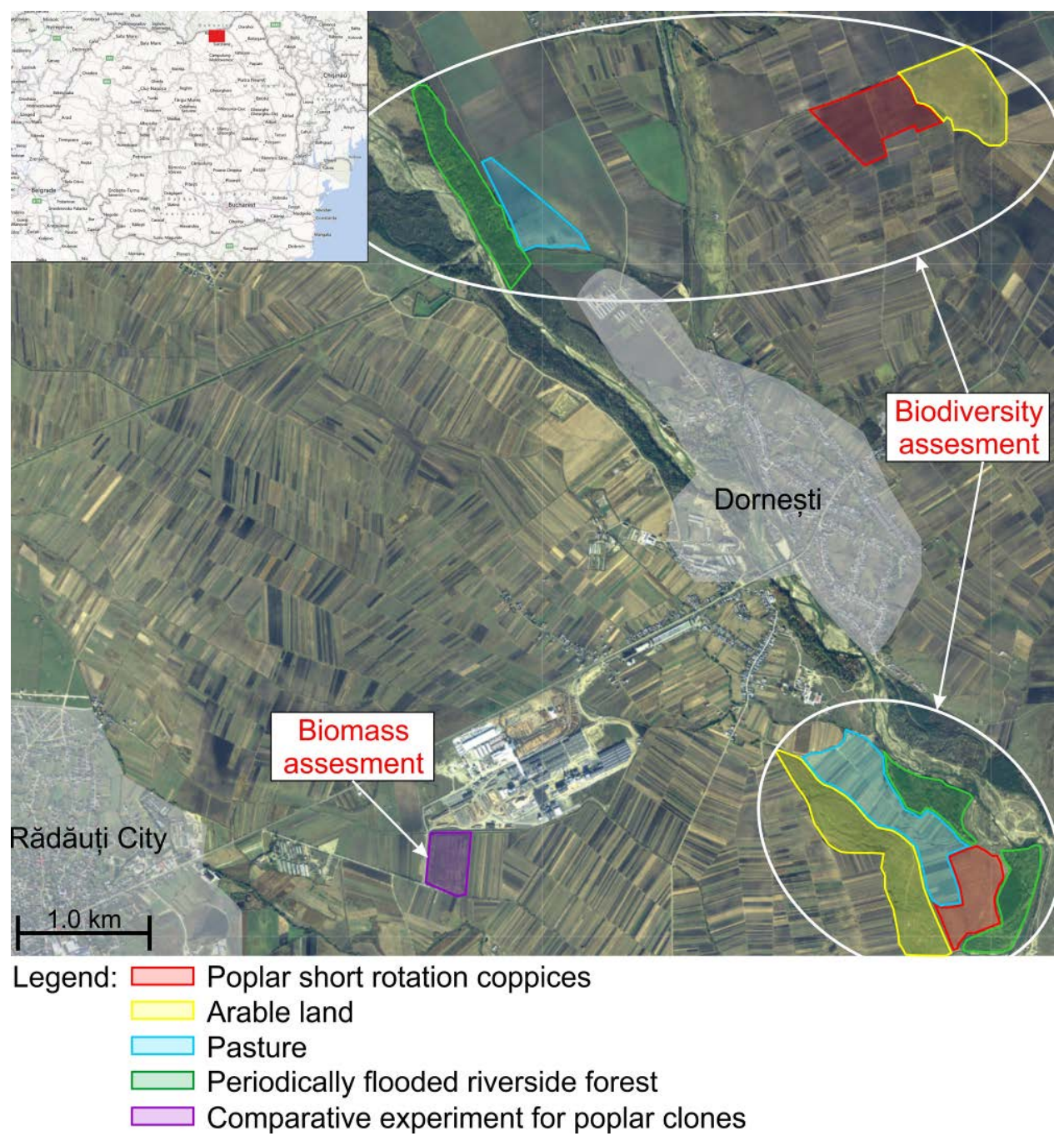

Figure 1 . The location of the study and the experimental design

\section{Environmental soil indices}

\section{RESULTS AND DISCUSSION}

The indices monitored targeted the influence of hybrid poplar crops on the chemical characteristics of the soil in terms of: nutrients consumption $(\mathrm{N}, \mathrm{P}, \mathrm{K})$, change of $\mathrm{pH}$ values and bases saturation (SB, V\%) and possible changes of the soil composition (quality) and organic matter quantity (humus). Monitoring the evolution of the soil chemical properties implied the annual extraction, at the beginning of the growing season (April-May), of a minimum of three soil samples from each poplar tree row and clone (AF2/AF8/Pannonia), from each crop type (black field/fallow) and from three other alternative land-uses, e.g. agricultural land (cultivated with wheat), pasture and forests from riparian zones. 
The samples were collected in the year previous to the poplar instalment, and the two years.

Results of the monitoring conducted three years in the experimental area show that one of the most accurate indicators of nutrient consumption was phosphorus (P). Thus, after only one growing season (2013-2014) the mobile phosphorus content (PAL) of the soil under poplar crops fell by almost $40 \%$, a higher consumption than under agricultural crops in the area. Certain studies conducted in hybrid poplar crops in Canada have shown that on soils with different trophic potential the phosphorus content $(\mathrm{P})$ had maximum effect in the accumulation of total plant biomass (Benoit et al., 2012). We have confirmed this finding also in our case, showing the clear correlation between the phosphorus content in soil and the aerial biomass accumulation (Savin et al., 2014). One other finding was that the nutrient consumption was not significantly different in the poplar culture as compared with the agricultural crop (namely, wheat crop). On the other hand, the content and the consumption of total nitrogen $(\mathrm{N})$ in the soil under the poplar crop is not always relevant because of the different mineralization rate of the humus. The same can be said of mobile potassium content (KAL), whose consumption is significantly lower and depends largely on soil texture (the percentage of clay) and not necessarily on the crop which consumes it.

The monitorization of nutrient content of soils under hybrid poplar crops will extend for a period of at least 5 years to better observe the consumption rate of macroelements from soil, especially phosphorus.

\section{Environmental biodiversity indices}

The investigations had as purpose the comparative analysis of biodiversity in poplar energy crops with the biodiversity of the agricultural lands (wheat crop and pasture) or and of the forests that are specific to the studied area (poplar, willow, and other species that form periodically flooded riverside forest). In this regard, analyses were made on plant communities from these ecosystems, on insect populations (namely, the population of various species of Carabidae Family as main biodiversity indicator) and on the populations of reptiles, amphibians, birds and mammals that use these ecosystems for shelter and food. The study was conducted in the four types of ecosystem present in two different locations.

To assess the plant biodiversity, in each analyzed area a sample surface of 1000 square meters was established, as structurally homogeneous as possible, in which all species of higher plants (cormophytes) were inventoried. For a better accuracy, this method was combined with transect observation. The observations related to plants were conducted in 2013 and 2014 growing seasons, in April, then in late May - early June, late July and early September.

The insect biodiversity study was limited to beetle species (Carabidae Family) as reliable indicators of biodiversity in the four types of land uses. In the central area of each analyzed surface (poplar plantation, riverside forest, pasture, 
agricultural crop) we have installed five Barber traps situated at a distance of at least $50 \mathrm{~m}$ each other. The traps were provided with a preserving liquid which allows the collection of trapped insects each two weeks. The traps worked over two seasons (2013 and 2014) from April to October.

To record presence of mammals (e.g. mustelides, brown hare, badger, fox, roe deer) we had to solve the problem of low density. Thus we have practiced the observations on the presence of different footprints on the snow during the winter time, and transect observation in the other seasons, registering the presence of specimens from the various species. The study on bird was conducted during 2013 and 2014. For birds, direct observations (visual and auditory) on the presence of certain species within the territory of the studied habitats were made.

The research has shown that there are certain differences in the biodiversity of the four types of uses, poplar crops slightly favoring biodiversity compared to agricultural crops. The richest biodiversity was found, as expected, in forest ecosystems. But the main finding remains that the poplar crops are at least at the same level of biodiversity than the alternative agricultural land use. That is similar to the results from other researches conducted in Europe and North America showing increased levels of biodiversity in energy and forest plantations in comparison with agricultural land (Willyard and Tikalsky, 2006; Rowe et. al., 2009; Weih et al., 2010).

Assessing the biomass production

The aim of this investigation where to find which cultivation scheme is more productive and to provide support to the investigations related with the soil nutrients consumption.

The adaptability of short-rotation poplar plantations to station conditions and climate was assessed by analyzing the productivity at the individual level and the stand level. A number of seven hybrid poplar clones (AF2, AF6, AF8, A4A, Pannonia, Monviso and Max4) were tested on different type of planting material and planting scheme used. The planting material used was cuttings $(\mathrm{L}=22 \mathrm{~cm})$, seedlings $(\mathrm{L}=180 \mathrm{~cm})$, and rooted seedlings $(\mathrm{L} \approx 65 \mathrm{~cm})$, which were tested for various planting schemes (3x0,58/1,16/1,12/2,5 meters). For each clone, the development dynamics from the time of installation until the end of a production cycle of 5 years (Dănilă et al., 2015) and total biomass accumulation at the end of the development cycle was analyzed. For the biomass productivity (Lehtonen et al., 2004; Picard et al., 2012), a number of direct measurements (by weight) on the green mass on parts of the tree (trunk and branches) were carried out, which in relation to the specific humidity were correlated with the circumference of the trunk at the height of $1 \mathrm{~m}$. The humidity percentage was determined by drying the sample in an oven at a temperature of $104^{\circ} \mathrm{C}$ until a constant weight between two successive weightings (accuracy 1 g) (Felix et al., 2008, Klašnja et al., 2012).

The findings indicate a similar productivity of the specimens from rooted seedlings and those from seedlings after 4 and 5 years from installation. Also we have confirmed that a too high a density of specimens per hectare accompanied 
by an artificial intake of nutrients does not necessarily lead to an increase in productivity, as shown by Bungart and Hüttl (2004).

\section{Assessing the social sustainability and integrating the concept of sustainability}

The investigations on social sustainability were structured along three axis. We have started by analysing the socio-demographic factors characterising the region of the study, e.g. the five localities near the poplar plantations. We have characterised the land use, the employment and traditional inhabitants activities, and the recent economic investments in the region. All these factors suggest an area with occupational problems (less than $25 \%$ of the active population has a stable employment and a salary) and with high pressure on land, mostly for agricultural uses, however agriculture for subsistence due to its low economic competitiveness. The inhabitants show however a propensity for continuing with the cultivation of land and with the traditional uses, irrespective of expected economic return.

The second axis focused on the characterisation of resource scarcity, e.g. the inventory of marginal lands and recently afforested lands. The marginal lands represent a possible land resource to be used for energetic wood cultures, especially in areas with very low forest cover. The potential for marginal lands afforestation was assessed by mapping the lands affected by soil erosion, landslides, excessive water content and human induced degradation. We have analysed a total number of 4312 land units projected in the national geographic system Stereografic 1970. As data sources for mapping we used aerial images taken in 2009 and photointerpretation keys extracted from the field work performed in representative areas for each type of marginal land considered. For the actual mapping, we used an ArcGIS environment, creating a georeferenced database with degradation parameters. Based on satellite imagines, we have identified that the marginal land may represent up to $20 \%$ of the total land in the municipalities of the departments Suceava and Botosani, that means in total 72661 ha. More than 3000 ha represent pastures in high degradation stage that are in the ownership of municipalities and that, theoretically, could be converted to the forest. The terrains affected by excessive water content (marshes), that could be more favorable for poplar cultures, were found on approximately 5000 ha.

These figures would indicate a mismanagement of land and in the same time, a high availability of land for other uses than the traditional ones. Taking into account this findings, we have proceed also to an inventory of recently created forest plantations (period 2005-2012) and of their stage after two-three years after afforestation. The evaluation of local measures for the afforestation of marginal lands in Suceava and Botoşani counties was done using a geodatabase containing the boundaries and parameters needed for the identification and assessment of perimeters reforested after 2005. The database is structured as a Geographical Information System, editable in ArcGIS, as a basis for maps and 
cartograms that synthetize the recent concerns regarding the ecological reconstruction of degraded lands. The total area of the land improvement projects implemented between 2005 and 2012 in the two counties was 3172,79 ha, with the former land use of communal pastures, in the property of local administrations. We have found in the field 726 ha plantations, representing only $22 \%$ of all the land specifically designated for improvement. From these, only $11 \%$ have achieved a stage that qualified them as a success: most of the plantations were in fact affected by grazing, intentional fire, severe drought in summer 2012, or they were compromised by the lack of know-how in the afforestation procedures or the discontinuities in financing the afforestation works. These findings leads us to take into account several hypothesis in investigation the low social acceptance of afforestation works or poplar cultures, that represented the third axis of research.

Thus, based on the socio-demographic profile and on the inventory of the resource, we have drawn a questionnaire targeting the rural inhabitants from the studied region. The questionnaire was based on the following hypothesis: 1) the inhabitants do not like poplar cultures because they prefer to keep traditional land uses; 2) the inhabitants do not like poplar cultures because they do not like the forests in general; 3) the inhabitants will not cultivate poplar because they do not perceive an utility of this culture. The questionnaire was tested on two communes, one in the proximity of poplar cultures $(51 \%$ of the population occupied in agriculture) and the second at $30 \mathrm{~km}$ distance from the poplar cultures (61\% of the population occupied in the agriculture), on a number of 88 respondents. The analysis of the results will allow to improve the questionnaire, projected to be fulfilled on a total number of 400 respondents from the five communities.

The final goal of the project is to integrate all these results (on soil, biodiversity, productivity, and social sustainability) in Guidelines for sustainable short-term cultures for biomass production, that will be discussed with the relevant stakeholders at the national and local level. We have projected to use a Delphi survey with experts to externally validate some of the main findings of the study, followed by workshops to elaborate the Guidelines.

\section{CONCLUSION}

The sustainability of short-term cultures for biomass production should be analyzed according to the purpose of the cultures and according to the scale of the potential impact. The purpose and scale of industrial utilization is different from the purpose and scale of plantation as carbon mitigation strategy: in one case one should analyze the costs and benefits repartitions (who bears the cost, and to whom belongs the benefits), in the second case more laborious analysis are needed, e.g. life cycle analysis method to see if finally the energetic use of woody biomass is or not an efficient solution in carbon mitigation strategies.

In our application, we have chosen to stick on a particular definition of sustainability: short-term rotation plantations on marginal or agricultural lands 
should produce benefits to local communities and industry while minimizing the environmental risks. We have investigated therefore some relevant environmental indices (soil and biodiversity related) for short-term poplar culture and three other alternative uses to conclude on the level of risks associated with the poplar culture. We have provided references about the influence of cultivation scheme on the productivity, with the idea to optimize the total biomass production according to the industry needs and the soil nutrient consumption. Finally, we have analyzed which is the social acceptability of the short-term biomass production when the cultures are not lead by the local communities, and the inhabitants do not like the change of the traditional land uses. The preliminary results show that the blueprints of sustainability assessments have to be adapted to context-specific situations. While the economic and environmental components of sustainability can be determined and monitored using well established techniques, the social component can differ and change rapidly being influence by institutional, cultural and even religious factors. In this context it is important to have a sound and objective assessment of the impact of short-rotation poplar plantations on the overall social benefits as to be able to provide clear messages to investors, communities, stakeholders and policy makers. The sustainability assessment resulting from this complex study would help to drawn, in a participatory and transparent way, a guide for sustainable short-term production of the woody biomass for industrial purposes.

\section{ACKNOWLEDGEMENTS}

The research was conducted within the PN II STRoMA project (Sustainability of short rotation forest species crops on land outside the forest fund). Project PCCA-2011-3.2-1574/ Contract no. 119/2012 financed by Executive Unit for Financing Higher Education, Research, Development and Innovation (UEFISCDI). We are grateful to our private partner who supported and helped us along the experiment implementation

\section{REFERENCES}

Al Afas, N., Marron, N., Van Dongen, S., Laureysens, I., Ceulemans, R., 2008 Dynamics of biomass production in a poplar coppice culture over three rotations (11 years), Forest Ecology and Management, Volume 255, Issues 5-6, 5, Pages 1883-1891, ISSN 0378-1127, 10.1016/j.foreco.2007.12.010.

Austroprojekt 2008. Forestry and forest industry in Romania. Wood sector study. Final Report April 2008 elaborated by AUSTROPROJEKT Agency for Technical Cooperation Ltd, Vienna. Report prepared for the European Bank of Reconstruction and Development and Ministry of Agriculture and Rural development, Romania. Unpublished document. 166 p.

Benea V., 1989. Selecţia si tehnologii de cultură a speciilor cu creştere rapidă (plop, salcie, salcâm) pentru produ $\neg$ cerea de fitomasă energetică. [Culture techniques and selection of fast growing tree species (poplars, willows and black locust) for energetic biomass production]. Technical report ICAS $35 \mathrm{p}$.

Benoit, B., Gagnon, D., Fortier J., Lambert et. Al, 2012. Yield in 8 year-old hybrid poplar plantations on abandoned farmland along climatic and soil fertility gradients 
Forest Ecology and Management. 03/2012; 267(1): pp228-239. DOI: 10.1016/j.foreco.2011.12.012

Bungart, R., \& Hüttl, R. F., 2004. Growth dynamics and biomass accumulation of 8-yearold hybrid poplar clones in a short-rotation plantation on a clayey-sandy mining substrate with respect to plant nutrition and water budget. European Journal of Forest Research, 123(2), 105-115.

Carnus, Jean-Michel, Parrotta, John, Brockerhoff, Eckehard, Arbez, Michel, Jactel, Hervé, Kremer, Antoine, Lamb, David, O'Hara, Kevin, Walters, Bradley, 2006. Forests and Biodiversity, Journal of Forestry, Volume 104, Number 2, March 2006, pp. 65-77(13)

Ceulemans, R., Deraedt, W., 1999, Production physiology and growth potential of poplars under short-rotation forestry culture, Forest Ecology and Management, Volume 121, Issues 1-2, Pages 9-23, ISSN 0378-1127, 10.1016/S03781127(98)00564-7.

Dănilă I., Avăcăriței, D., Alexei, S., Roibu, C., Bouriaud, O., Duduman, M., Bouriaud, L., 2015. Dinamica şi caracteristicile creşterii a şase clone de plop hibrid pe parcursul unui ciclu de producţie într-o plantaţie comparativă din Depresiunea Rădăuţi. Bucovina Forestieră, 15(1), 19-30.

Dickmann, D. I., 2006. Silviculture and biology of short-rotation woody crops in temperate regions: Then and now. Biomass and Bioenergy, Volume 30, Issues 89, August-September 2006, Pages 696-705. Proceedings of the 5th Biennial meeting of the Short Rotation Woody Crops Operations Working Group in conjunction with International Energy Agency Bioenergy, Task 30, Short Rotation Crops for Bioenergy Systems and International Union of Forest Research Organization, Working Unit 1.09.01, Integrated Research in Temperate ShortRotation Energy Plantations

Dragoi, M., 2008, Analiza cost-beneficiu a conversiei pădurilor naturale în plantații de plop. Report on Conservarea și managementul integrat al ostroavelor de pe Dunăre, România, LIFE06/NAT/RO 000177

FAO - UNECE, 2011, The European Forest Sector Outlook Study II 2010-2030, United Nations publication, ISSN 1020-226

Fara L., Filat M., Chira D., Fara S., Nuţescu C., 2009: Preliminary research on short cycle poplar clones for bioenergy production. Proceedings: RIO 9 - World Climate \& Energy Event. Rio de Janeiro, Brazilia. 127-132.

FELIX, E., TILLEY, D. R., FELTON, G. \& FLAMINO, E. 2008. Biomass production of hybrid poplar (Populus sp.) grown on deep-trenched municipal biosolids. ecological engineering, 33, 8-14.

Filat M., Chira D., 2004: Cercetări privind introducerea în cultură de specii / clone de plop şi salcie cu potenţial silvoproductiv superior şi rezistenţă sporită la adversităţi. Anale ICAS, Seria I, 47: 83-99.

Fletcher, RJ, Robertson, BA, Evans, J, Doran, PJ, Alavalapati, JRR and Schemske, DW, 2011. Biodiversity conservation in the era of biofuels: risks and opportunities. Frontiers in Ecology and the Environment, Volume: 9 Issue: 3 Pages: 161-168, April 2011

Grigal, D., 2000, Effects of extensive forest management on soil productivity, Forest Ecology and Management, Volume 138, Issues 1-3, 1 Pages 167-185, ISSN 0378$1127,10.1016 /$ S0378-1127(00)00395-9.

Hall, J. P. (2002). Sustainable production of forest biomass for energy. The Forestry Chronicle, 78(3), 391-396. 
Hartmuth G, Huber K, Rink D., 2008. Operationalization and contextualization of sustainability at the local level. Sustain Dev 16: 261-70.

http://probiopa.imk-ifu.kit.edu/

Klašnja, B., Orlović S. \& Galić, Z. 2012. Energy potential of poplar plantations in two spacings and two rotations. Šumarski list, 136, 161-167.

Lăzăroiu G., 2008. Tehnologii alternative de înlocuire a combustibililor gazoşi prin utilizarea durabilă, combinată a resurselor forestiere şi de cărbune. [Alternative technologies for replacing gas fuels by sustainable utilization, combined with forestry and coal resources]. Technical report ICAS.

Lehtonen, A., Mäkipä R., Heikkinen J., Sievänen R. \& Liski, J. 2004. Biomass expansion factors (BEFs) for Scots pine, Norway spruce and birch according to stand age for boreal forests. Forest Ecology and Management, 188, 211-224.

Lindberg JE, Tolbert VR, Schiller A, Hanowski J, 1998. Determining biomass crop management strategies to enhance habitat value for wildlife, Poster from BioEnergy '98: Expanding Bioenergy Partnerships, Madison, WI, October 4-8, 1998.

Loyola-Bernard, 2012. Les centrales solaires et la protection des espaces ruraux et littoraux. Mémoire du master professionnel « Droit de la protection de l'environnement - Territoires méditerranéens », Université Paul Cézanne Aix Marseille III, 72 p.

MAFRD, 2010. National Programm for Rural Development, Measure 221: First afforestation of agricultural land.

Mantau, U. et al. 2010: EUwood - Real potential for changes in growth and use of EU forests. Final report. Hamburg/Germany, June 2010. 160 p.

MEF, 2010. Programul național de împădurire (National Afforestation Programme). Ministry of Environment and Forests. Available in June 2011 at http://www.mmediu.ro/paduri/informatii/17.11.2010_Programul-NationalImpadurire.pdf

Monitorul Oficial, 2010. Legea nr. 100/2010 privind împădurirea terenurilor degradate (Law on afforestation of badlands). Publicată în Monitorul Oficial, Partea I nr. 376 din 07/06/2010

Muşat I., 1983. Tehnologii de instalare, întreţinere, conducere şi recoltare mecanizată a culturilor de plop şi salcie selecţionată de mare valoare energetică şi industrială. [Installation, maintaining, leading and mechanized harvesting technologies of the poplar and willows cultures, selected for height energetically and industrial value]. Technical report ICAS.

Pearce D, Markandya A, Barbier E., 1989. Blueprint for a green economy. Earthscan. London, 1989.

Pellis A, Laureysens, I., Ceulemans, R., 2004. Growth and production of a short rotation coppice culture of poplar I. Clonal differences in leaf characteristics in relation to biomass production, Biomass and Bioenergy, Volume 27, Issue 1, Pages 9-19, ISSN 0961-9534, 10.1016/j.biombioe.2003.11.001.

Picard N., Saint-André, L. \& Henry, M. 2012. Manual for building tree volume and biomass allometric equations: from field measurement to prediction.

Rawls, J.,1999. A Theory of Justice, rev. ed. Cambridge, MA: Belknap, 5.

Riffell, S, Verschuyl, J, Miller, D, Wigley, TB, 2011. A meta-analysis of bird and mammal response to short-rotation woody crops. Global Change Biology Bioenergy, Volume: 3, Issue: 4, Pages: 313-321, August 2011 
Rowe, L., Street, R., Taylor, G., 2009. Identifying potential environmental impacts of large-scale deployment of dedicated bioenergy crops in the UK, Renewable and Sustainable Energy Reviews 13 (1): 271-290

Savin A., Trifan O., Covatariu S., Ciurla S., Bouriaud L., 2014. Influenta profunzimii solurilor aluviale asupra biodiversității subterane și a unor caracteristici biometrice în culturi de clone de plopi hibrizi. Rezultate preliminare. Bucovina forestiera, $\mathrm{nr}$ 14 (1):60-67.

Scholz, V. and Ellerbrock, R., 2002. The growth productivity, and environmental impact of the cultivation of energy crops on sandy soil in Germany, Biomass and Bioenergy, Volume 23, Issue 2, August 2002, Pages 81-92

Smith, C.S. and McDonald G.T., 1998. Assessing the sustainability of agriculture at the planning stage. J Environ Manage 1998; 52:15-37.

Thevathasan, N., Andrew Gordon, Jamie Simpson, Xiaobang Peng, Salim Silim, Raju Soolanayakanahally, and Henry de Gooijer. 2014. Sustainability Indicators of Biomass Production in Agroforestry Systems. Open Agriculture Journal 8 (2014): 1-11.

Turcu D., 2006. Realizarea unei culturi energetice forestiere (sursă energetică regenerabilă) într-o zonă slab productivă pentru culturi agricole, în scopul verificării rezistenţei speciilor şi varietăţilor de arbori cu creştere rapidă în condiţii de sol degradat, evaluarea producţiei de lemn (biomasă), selectarea unor tehnologii mecanizate de cultivare/recoltare şi tocare, în vederea utilizării energetice. [The establishment of an forestry energetic culture in low agricultural productivity zone for investigating fast growing tree species resistance to degradated soil conditions, biomass production evaluation and selection of mechanized cultivation and harvesting technologies]. Technical report ICAS.

UNECE, 2011, The Forest Products Annual Market Review.

Vande Walle, I., Van Camp, N., Van de Casteele, L., Verheyen, K., Lemeur, R., 2007, Short-rotation forestry of birch, maple, poplar and willow in Flanders (Belgium) I-Biomass production after 4 years of tree growth, Biomass and Bioenergy, Volume 31, Issue 5, Pages 267-275, ISSN 0961-9534, 10.1016/j.biombioe.2007.01.019.

Wang, Lijun, ed. 2014. Sustainable bioenergy production. CRC Press, 2014.

Weih, M., Sarah Baum, Bolte, A., 2010. Flora-diversity in Swedish willow and poplar stands: Woody energy crops can improve biodiversity in agricultural landscape, CRA - Open Conference System, Fifth International Poplar Symposium (IPS V)

Willyard, C., Tikalsky, S., 2006, Bioenergy in Wisconsin: The Potential Supply of Forest Biomass and Its Relationship to Biodiversity, Environmental Research Program, Final Report, Resource Strategies, Inc., Madison, Wisconsin 